DOI: 10.46340/eppd.2020.7.3.4

Viktor Dubovyk, PhD in Law

ORCID ID: https://orcid.org/0000-0002-4258-6594

\title{
PECULIARITIES OF THE ENVIRONMENTAL DIMENSION OF OSCE ACTIVITY
}

\author{
Віктор Дубовик, к.ю.н. \\ ОСОБЛИВОСТІ ЕКОЛОГІЧНОГО ВИМІРУ \\ ДІЯЛЬНОСТІ ОБСЕ
}

The article analyzes the environmental priority and at the same time the dimension of OSCE activities according to the Helsinki Final Act of 1975, and its expansion and change in recent years. It was established that the Organization for Security and Cooperation in Europe has been found to work for stability, prosperity, and democracy in 56 countries. In particular, its purpose is to promote political dialogue on common values and to provide practical work aimed at improving the international security system. The text of the article emphasizes the need for a comprehensive academic analysis of current challenges to the international security system. In addition, special attention has been paid to the three main dimensions of OSCE activity, namely: political-military, economic-environmental, and human. It is noted that the OSCE addresses a wide range of security issues, including arms control, preventive diplomacy, confidence- and security-building measures, human rights, election monitoring, democratization, and economic and environmental activities.

Keywords: security, conflict (political, armed), OSCE, CSCE, political-military dimension, economic dimension, human dimension.

Постановка проблеми. У Документі-стратегії держави-учасниці ОБСЄ визнали, що «екологічна деградація, нестійке користування природними ресурсами і неправильне управління переробкою та знищенням відходів мають істотний негативний вплив на здоров'я, добробут, стабільність і безпеку населення наших країн». Визнаючи тісний зв’язок між навколишнім середовищем і безпекою, ОБСС прагне зміцнювати співробітництво з екологічних питань в рамках більш широких зусиль щодо запобігання конфліктів, зміцненню взаємної довіри і розвитку добросусідських відносин.

Відтак метою статті є встановлення особливостей запровадження екологічного виміру в діяльності НБСЄ, а пізніше ОБСЄ.

Виклад дослідження. Працюючи в партнерстві з міжнародними організаціями, національними урядами та громадянським суспільством, ОБСЄ вирішує питання екології та безпеки за багатьма різними напрямками. Організація підтримує проекти і діяльність щодо забезпечення сталого управління природними ресурсами, зокрема водними, всередині країни і між країнами, зменшення ризику катастроф, вирішення проблем зміни клімату та безпечного керування небезпечними відходами. ІЇ̈ робота спрямована також на підвищення інформованості в питаннях екології, стимулювання участі громадськості в прийнятті рішень, що стосуються навколишнього середовища, і на полегшення доступу до правосуддя з питань охорони навколишнього середовища, зокрема за допомогою Орхуських центрів ${ }^{1}$.

Окремо слід відмітити, що ОБСЄ підтримує діалог з питань енергетики між своїми державами-учасниками, в число яких входять провідні в світі країни - виробники енергії, країниспоживачі і країни транзиту. Діяльність ОБСЄ охоплює енергетичну безпеку, включаючи розвиток поновлюваних джерел енергії і пошук вирішення проблем переходу до надійного енергопостачання, підвищення мережевої стійкості, енергетичну ефективність і зелене зростання ${ }^{2}$.

\footnotetext{
${ }^{1}$ OSCE (2020). What is the OSCE? <https://www.osce.org/whatistheosce/factsheet?download=true> (2020, квітень, 24).

${ }^{2}$ НІСД (2013). ОБСЕ: сучасні виклики та перспективи розвитку. Аналітична доповідь.

$<$ https://niss.gov.ua/sites/default/files/2013-12/0312_dopovid.pdf> (2020, квітень, 24).
} 
Так, здійснювана за сприяння ОБСЄ діяльність спрямована на забезпечення сталого розвитку та належного управління навколишнім середовищем в регіоні ОБСЄ і за його межами.

Бюро Координатора економічної та екологічної діяльності ОБСЄ (БКЕЕД) здійснює проекти в тісній співпраці з польовими операціями ОБСЄ; організовує щорічний Економіко-екологічний форум; i проводить щорічну нараду з питань виконання 3 метою оцінки прогресу у виконанні державами - учасницями ОБСС взятими на себе зобов'язань в економіко-екологічній сфері та визначення пріоритетів для подальшої роботи. Бюро працює в тісній співпраці з головуванням організації під керівництвом Економіко-екологічного комітету, допоміжного органу Постійної ради ${ }^{1}$.

32003 року ОБСЄ тісно співпрацює з іншими міжнародними організаціями в рамках ініціативи "Навколишнє середовище та безпека" (ENVSEC), яка служить концептуальною основою для співпраці з питань екології та безпеки як всередині, так і за межами країн. В рамках цієї ініціативи ОБСЄ працює над забезпеченням миру і стабільності на основі співпраці в галузі охорони навколишнього середовища і сталого розвитку в Південно-Східній Європі, Східній Європі, на Південному Кавказі і в Центральній Азії. ОБСЄ протистоїть викликам в області екології і безпеки також в рамках свого партнерства з середземноморськими та азійськими партнерами ОБСЄ із співробітництва 2 .

В області енергетики ОБСЄ взаємодіє з членами Віденського енергетичного клубу, СЕК ООН, секретаріатом Енергетичної хартії і Міжнародним енергетичним агентством.

Робота ОБСС в екологічній сфері ${ }^{3}$ ведеться БКЕЕД із основним акцентом на: проблем;

сприяння розвитку транскордонного співробітництва в справі подолання екологічних

надання національним органам державної влади підтримки в реалізації багатосторонніх природоохоронних угод;

нарощування на місцевому, національному та регіональному рівнях потенціалу щодо подолання екологічних викликів, які можуть впливати на стан в галузі безпеки;

сприяння розробці та перегляду природоохоронного законодавства, стратегій та планів 3 метою забезпечення дотримання міжнародних стандартів і виконання зобов'язань в різних сферах; полегшення сталого управління природними ресурсами з особливим акцентом на водокористування;

забезпечення інформованості про вплив кліматичних змін на безпеку і сприяння розробці та виконанню стратегій адаптації до транскордонних змін клімату;

надання підтримки в справі забезпечення готовності на випадок екологічних лих, їx попередження та реагування на них $\mathrm{i}$ подолання їх наслідків на рівні громад, а також на національному та транскордонному рівнях;

нарощування потенціалу з виявлення та попередження злочинів у сфері екології, в тому числі на кордонах;

заохочення сталого управління небезпечними відходами та речовинами;

зміцнення потенціалу громадянського суспільства в пошуку шляхів подолання екологічних проблем і проблем в сфері безпеки;

сприяння систематичного обліку гендерної проблематики i ефективному залученню жінок i молоді в діяльність із захисту навколишнього середовища;

нарощування потенціалу на регіональному рівні та підвищення обізнаності щодо сталої енергетики, а також сприятливих можливостей і викликів у справі перебудови діяльності державного і приватного сектора в енергетичній галузі; а також протидія загрозам найважливішим неядерних об'єктів енергетичної інфраструктури;

підвищення обізнаності про екологічні проблеми, просування теми транспарентності i забезпечення участі громадськості в прийнятті рішень, а також доступу до правосуддя в екологічній сфері, зокрема за допомогою Орхуських центрів.

Орхуські центри, будучи значною частиною інституційного забезпечення функціонування екологічного руху в рамках міжнародної спільноти, базується на Орхуській Конвенції, що наділяє

\footnotetext{
${ }^{1}$ OSCE (2020). What is the OSCE? < https://www.osce.org/whatistheosce/factsheet?download=true> (2020, квітень, 24).

${ }^{2}$ ОБСЕ / БДИПЧ (2011). Обязательства ОБСЕ в области человеческого измерения (Сборник документов

в тематическом порядке). Варшава: Бюро ОБСЕ по демократическим институтам и правам человека, 1 .

${ }^{3}$ OSCE (2020). What is the OSCE? <https://www.osce.org/whatistheosce/factsheet?download=true> $(2020$, квітень, 24).
} 
громадськість правом доступу до інформації, іiі участі в процесі прийняття рішень та доступу до правосуддя 3 питань, що належать до захисту навколишнього середовища на місцевому та національному рівнях, а також в транскордонному контексті ${ }^{1}$. Сюди належить:

1) доступ до екологічної інформації - право кожного отримувати екологічну інформацію, наявну у державних органів. Це може включати інформацію про стан навколишнього середовища, а також про політику або заходи, які вживаються, або про стан здоров'я та безпеки людей, коли вони порушуються;

2) участь громадськості в процесі прийняття рішень з екологічних питань- право брати участь в процесі прийняття рішень з екологічних питань, наприклад, шляхом надання коментарів до проектів законів, проектів і програм у сфері охорони довкілля;

3) доступ до правосуддя - право звернення до суду і вимагати перегляду прийнятих рішень, якщо при їх підготовці не були належним чином враховане національне екологічне законодавство в цілому. Таким чином, Конвенція відображає і просуває, охоплюючи всі вимірювання даної теми, зв'язок між правами громадян і захистом навколишнього середовища 2 .

Підтримка з боку ОБСЄ створення інформаційних центрів $є$ важливим чинником сприяння процесам управління охороною навколишнього середовища на національному рівні.

Важливо відзначити, що Конвенція унікальна в сенсі зв'язування захисту навколишнього середовища $з$ підзвітністю і транспарентністю урядів, їх готовністю відповідати на потреби і запити громадян. У той час, як більшість багатосторонніх екологічних угод встановлює зобов'язання в міжнародному контексті, Орхуська Конвенція накладає зобов'язання по відношенню до громадськості на відповідні національні органи‥

Починаючи з 2003 р. ОБСС надавала підтримку створенню Орхуських Центрів та Центрів громадської екологічної інформації, виступаючи в тісній співпраці з Ініціативою в області навколишнього середовища і безпеки (ЕНВСЕК) - партнерства між ОБСЄ, ЮНЕП, ПРООН, СЕК $\mathrm{OOH}$ та Регіональним екологічним центром, а також НАТО в якості асоційованого партнера ${ }^{4}$.

Натомість повертаючись до діяльності БКЕЕД, що займається питаннями водних ресурсів в рамках Ініціативи ЕНВСЕК і в тісній співпраці з Секретаріатом Конвенції СЕК ООН з охорони та використання транскордонних водотоків та міжнародних озер. Вона розробила програму дій щодо поліпшення правового регулювання водних ресурсів річки Дністер, які діляться Україною та Молдовою, i ініціювала формування мережі місцевих зацікавлених учасників в управлінні ресурсами річки Сава в Південно-Східній Європі. ОБСЄ також підтримує регіональний транскордонний моніторинг річок в басейні річок Кура / Аракс / $\mathrm{Apac}^{5}$.

Багато в чому проект «Громадяни за безпеку і навколишнє середовище» (ГБОС) являє собою досить просту ідею, але цілі у нього досить вражаючі. Ця програма, реалізація якої була розпочата Бюро Координатора економічної та екологічної діяльності ОБСЄ в 2009 році і яка фінансується в рамках ініціативи «Навколишнє середовище та безпека» (ЕНВСЕК), надає невеликі гранти в розмірі від 5000 до 10000 євро організаціям громадянського суспільства в регіонах, де прихильники практики належного управління в сфері екології можуть стикатися з труднощами в отриманні фінансової і політичної підтримки ${ }^{6}$.

\footnotetext{
${ }^{1}$ Emerson, M. (2008). Emerson Michael. The Struggle for a Civilised Wider European Order. Elements for a European Security Strategy. CEPS Working Document No. 307/October, 28.

2 ОБСЕ / БДИПЧ (2011). Обязательства ОБСЕ в области человеческого измерения (Сборник документов в тематическом порядке). Варшава: Бюро ОБСЕ по демократическим институтам и правам человека, 1.

${ }^{2}$ OSCE (2020). What is the OSCE? <https://www.osce.org/whatistheosce/factsheet?download=true> (2020, квітень, 24).

${ }^{3}$ Rojansky, M. (2011) A Euro-Atlantic security community for the 21st century. Euro-Atlantic Security Initiative. Building bridges. Security community and partnerships for change. Austria: The Organization for Security and Co-operation in Europe, 19-25.

${ }^{4}$ НІСД (2013). ОБСЕ: сучасні виклики та перспективи розвитку. Аналітична доповідь.

$<$ https://niss.gov.ua/sites/default/files/2013-12/0312_dopovid.pdf> (2020, квітень, 24).

${ }^{5}$ ОБСЕ / БДИПЧ (2011). Обязательства ОБСЕ в области человеческого измерения (Сборник документов в тематическом порядке). Варшава: Бюро ОБСЕ по демократическим институтам и правам человека, 1 .

${ }^{5}$ OSCE (2020). What is the OSCE? < https://www.osce.org/whatistheosce/factsheet?download=true> (2020, квітень, 24).

${ }^{6}$ Rojansky, M. (2011) A Euro-Atlantic security community for the 21st century. Euro-Atlantic Security Initiative.

Building bridges. Security community and partnerships for change. Austria: The Organization for Security and Co-operation in Europe, 19-25.
} 
Старт реалізації ГБОС був дан в Вірменії та Азербайджані. Починаючи з 2010 року гранти по лінії ГБОС надаються також в Таджикистані, де особлива увага приділяється підтримці сільських НПО у віддалених районах, в яких, на відміну від столиці, відсутні ресурси для екологічної освіти населення. У всіх трьох країнах програма ГБОС спирається на підтримку Орхуських центрів і в той же час посилює їх роботу.

Відбір відповідних проектів здійснюється Національної відбірковою комісією ГБОС, до складу якої входять представники уряду, громадянського суспільства і міжнародних організацій, а затверджуються ці проекти відповідно до узгодженої стратегією ГБОС у відповідній країні. На даний момент підтримку по лінії ГБОС отримали вже 36 проектів. Провідну роль у фінансуванні цієї програми грають Австрія, Канада, Люксембург, Сполучені Штати тощо .

Висновки. Організація з безпеки і співробітництва в Свропі працює в ім'я стабільності, процвітання і демократії в 56 державах. Вона налагоджує політичний діалог з питань загальних цінностей, і веде практичні роботу, націлену на те, щоб зробити наш світ кращим. У мандат ОБСЄ визнається необхідність займатися викликами безпеки, просуваючись по шляху розширення співпраці і проявляючи всебічний підхід. Фокусуючи увагу на трьох вимірах - політиковійськовому, економіко-екологічному і людському - ОБСЄ займається широким колом питань безпеки, включаючи контроль над озброєннями, превентивну дипломатію, заходи по зміцненню довіри i безпеки, права людини, моніторинг виборів, демократизацію, а також економічну i екологічну діяльність.

\section{References:}

1. OSCE (2020). What is the OSCE? <https://www.osce.org/whatistheosce/factsheet?download=true> (2020, April, 24). [in English].

2. NISD (2013). OBSYE: suchasni vyklyky ta perspektyvy rozvytku. Analitychna dopovid [OSCE: current challenges and prospects for development. Analytical report] <https://niss.gov.ua/sites/default/files/2013-12/0312_dopovid.pdf $>$ (2020, April, 24). [in Ukrainian].

3. OSCE / ODIHR (2011). Obyazatelstva OBSE v oblasti chelovecheskogo izmereniya (Sbornik dokumentov $v$ tematicheskom poryadke) [OSCE Commitments in the Human Dimension (Thematic Collection of Documents)]. Warsaw: OSCE Office for Democratic Institutions and Human Rights, 1. [in Russian].

4. Emerson, M. (2008). Emerson Michael. The Struggle for a Civilised Wider European Order. Elements for a European Security Strategy. CEPS Working Document No. 307/October, 28. [in English].

5. Rojansky, M. (2011) A Euro-Atlantic security community for the 21st century. Euro-Atlantic Security Initiative. Building bridges. Security community and partnerships for change. Austria: The Organization for Security and Co-operation in Europe, 19-25. [in English].

\footnotetext{
1 Там само.
} 